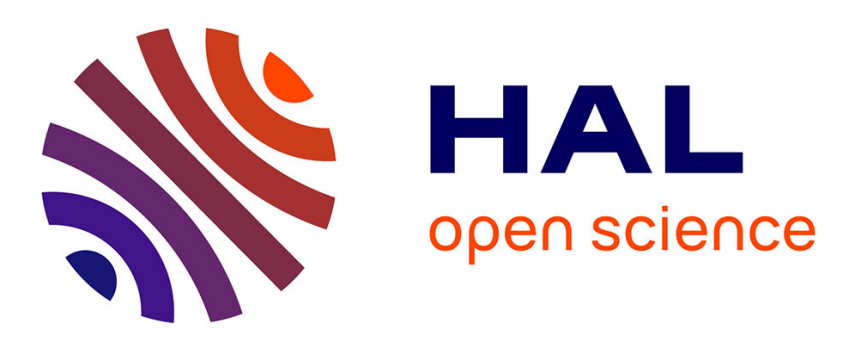

\title{
Solubility of carbon dioxide in three lipid-based biocarriers
}

\author{
A. R. Sampaio De Sousa, Marilyn Calderone, Élisabeth Rodier, Jacques \\ Fages, Catarina M. M. Duarte
}

\section{- To cite this version:}

A. R. Sampaio De Sousa, Marilyn Calderone, Élisabeth Rodier, Jacques Fages, Catarina M. M. Duarte. Solubility of carbon dioxide in three lipid-based biocarriers. Journal of Supercritical Fluids, 2006, 39 (1), pp.13-19. 10.1016/j.supflu.2006.01.014 . hal-01618301

\section{HAL Id: hal-01618301 https://hal.science/hal-01618301}

Submitted on 13 Dec 2017

HAL is a multi-disciplinary open access archive for the deposit and dissemination of scientific research documents, whether they are published or not. The documents may come from teaching and research institutions in France or abroad, or from public or private research centers.
L'archive ouverte pluridisciplinaire HAL, est destinée au dépôt et à la diffusion de documents scientifiques de niveau recherche, publiés ou non, émanant des établissements d'enseignement et de recherche français ou étrangers, des laboratoires publics ou privés. 


\title{
Solubility of carbon dioxide in three lipid-based biocarriers
}

\author{
A.R. Sampaio de Sousa ${ }^{a}$, Marilyn Calderone ${ }^{b}$, Elisabeth Rodier ${ }^{b}$, \\ Jacques Fages ${ }^{\mathrm{b}}$, Catarina M.M. Duarte ${ }^{\mathrm{a}, *}$ \\ a Nutraceuticals and Delivery Laboratory, ITQB/IBET, Aptd. 12-2781-901, Oeiras, Portugal \\ b Chemical Engineering Laboratory for Particulate Solids, École des Mines d'Albi-Carmaux, F81013 Albi, France
}

\begin{abstract}
Equilibrium data of the solubility of carbon dioxide in Precirol ${ }^{\circledR}$ ATO5, Compritol ${ }^{\circledR} 888$ ATO and Gelucire ${ }^{\circledR}$ 43-01, three solid lipid carriers suitable for controlled/sustained delivery, were measured by a static analytical method for three different temperatures each, in a pressure range from 10 to $20 \mathrm{MPa}$. The influence of the presence of carbon dioxide in the melting point of the lipid matrices was also studied by a visual method for pressures up to $30 \mathrm{MPa}$. All the compounds studied presented a similar behaviour in the presence of carbon dioxide, showing a decrease in the melting points between 5 and $13{ }^{\circ} \mathrm{C}$, whereas the solubility of carbon dioxide varies from 0.3 to $0.5 \mathrm{~g} / \mathrm{g}$ of lipid compound. These results are of utmost importance to design supercritical fluid processes for particle formation at lower operating costs.
\end{abstract}

Keywords: Precirol ${ }^{\circledR}$ ATO5; Compritol ${ }^{\circledR} 888$ ATO; Gelucire ${ }^{\circledR} 43-01$; Triglycerides; Melting point; Carbon dioxide; Solubility

\section{Introduction}

The development of new drugs faces a series of usual problems that vary in a wide range on nature, from physical-chemical problems (solubility-stability), to the routes of administration (bioavailability, excipients, regulatory issues, particle size) and to engineering problems (scale-up production) [1]. To overcome these problems, and to improve the in vivo properties of bioactive ingredients, either drugs or nutraceuticals, the development of suitable carriers as well as the adequate techniques to bind the compounds is required. Lipid particles are extremely promising carriers. With regard to parenteral application they have excellent stability, they protect the incorporated labile drugs from degradation and can be used for controlled release systems [2]. Even the potential disadvantages they might have, such as insufficient drug loading capacity and polymorphic transitions during storage, which leads to drug expulsion, can be avoided with an accurate choice of compounds. The less perfect the lipid matrix is, the better it will be to ensure more drug loading and less phase transitions. Therefore, the use of complex lipids, with different molecules and different chain lengths is a great choice in terms of preparation of controlled release systems with improved pharmacological/therapeutic properties [3].

\footnotetext{
* Corresponding author. Tel.: +351 214469727; fax: +351 214421161.

E-mail address: cduarte@itqb.unl.pt (C.M.M. Duarte).
}

Precirol ${ }^{\circledR}$ ATO5 $\left(\mathrm{C}_{16}\right.$ and $\left.\mathrm{C}_{18}\right)$, Compritol ${ }^{\circledR} 888$ ATO $\left(\mathrm{C}_{22}\right)$ and Gelucire ${ }^{\circledR}$ 43-01 $\left(\mathrm{C}_{12}-\mathrm{C}_{18}\right)$ are naturally-derived lipid matrices mainly composed of glyceryl fatty acids $\left(\mathrm{C}_{12}-\mathrm{C}_{22}\right)$. They have been used to enhance the bioavailability of sensitive drugs, to protect active ingredients from light, moisture and oxidation and as controlled release agents [3-10]. Furthermore, the fact that they are made from biocompatible natural matrices decreases the danger of toxicity, making them suitable not only for pharmaceutical but also to food and nutraceuticals industry. These compounds are regarded as GRAS (generally recognized as safe) products by Food and Drug Administration.

Supercritical fluid (SCF) technology has been shown to be a viable option in the formulation of particulate drug delivery systems [11-18]. The unique solvent tuneability of supercritical fluids, from gas-like to liquid-like properties, offers the possibility of precise control over the operative parameters, leading to production of particles with controllable morphology, narrow size distribution and low static charge. One of the SCF techniques to produce particles is known as PGSS ${ }^{\circledR}$ - Particles from Gas Saturated Solutions [16]. These gas saturated solutions are formed by dissolving a compressed gas in the bulk of a liquid. The mixture is then rapidly expanded through a nozzle, causing the complete evaporation of the gas and solidification of the liquid. During expansion the liquid cools down below its solidification temperature, due to the Joule-Thompson effect, thus forming fine particles [17]. Unlike other SCF processes, PGSS $^{\circledR}$ allows to form particles of substances that do not need 
to be soluble in carbon dioxide [18]. The critical condition in this case is the melting behaviour of the compound in the presence of carbon dioxide.

In this work, the influence of carbon dioxide in the melting point of the three lipid matrices, Precirol ${ }^{\circledR}$ ATO5, Compritol ${ }^{\circledR}$ 888 ATO and Gelucire ${ }^{\circledR} 43-01$, was studied by a visual method for pressures up to $30 \mathrm{MPa}$. Equilibrium data of the solubility of carbon dioxide in the lipid mixtures was measured by a static analytical method for three different temperatures each, in a pressure range from 10 to $20 \mathrm{MPa}$.

\section{Experimental}

\subsection{Materials}

Precirol ${ }^{\circledR}$ ATO5, Compritol ${ }^{\circledR} 888$ ATO and Gelucire ${ }^{\circledR}$ 43-01 were kindly provided by Gattefossé. According to the supplier Precirol ${ }^{\circledR}$ ATO5 is mainly composed of palmitic and stearic acids $\left(\mathrm{C}_{16}\right.$ and $\left.\mathrm{C}_{18}\right)$, Compritol ${ }^{\circledR} 888$ ATO is mainly composed of behenic acid $\left(C_{22}\right)$ and Gelucire ${ }^{\circledR} 43-01$ is a mixture of saturated fatty acids with carbon chains from $\mathrm{C}_{12}$ to $\mathrm{C}_{18}$. Carbon dioxide (99.998 mol\%) was supplied by Air Liquide and chloroform ( $99 \%$ ) by Panreac Quimica SA.

\subsection{Experimental procedures}

In this study two different methods were used to investigate the incorporation of carbon dioxide in Precirol ${ }^{\circledR}$ ATO5, Compritol $^{\circledR} 888$ ATO and Gelucire ${ }^{\circledR}$ 43-01. A visual method was applied to measure the variation of the compounds' melting points in the presence of carbon dioxide, and a static analytical method was applied to quantify the amount of carbon dioxide solubilized in the lipid matrices.

\subsection{Melting point determination}

The variation in the melting point of the lipidic mixtures was measured in a high-pressure apparatus, schematically presented in Fig. 1, in a similar method to the one described by FuknéKokot et al. [19]. Briefly, a sample is placed inside a capillary tube, which by its turn is inserted in a high-pressure cell with sapphire windows, with an internal volume of approximately $4 \mathrm{~cm}^{3}$. The desired amount of carbon dioxide is pumped into the cell,

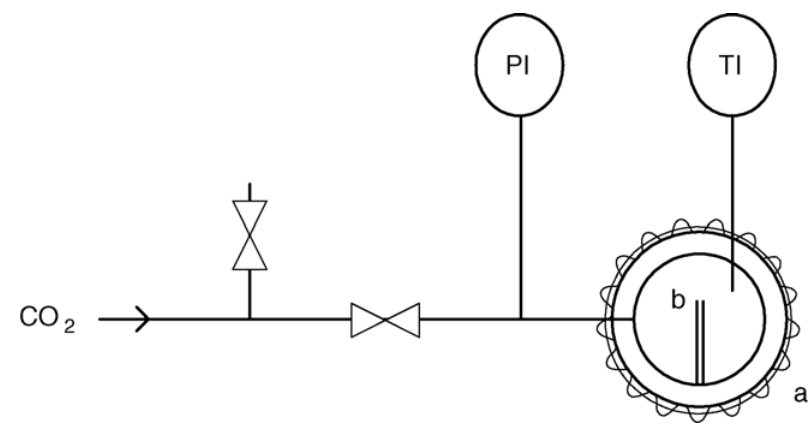

Fig. 1. High-pressure apparatus for melting point measurements: (a) heated sapphire-windowed cell and (b) capillary tube. with an accuracy of $0.05 \mathrm{MPa}$ and then temperature is continuously increased until the last solid particle melts. Measurements were performed in a pressure range up to $30 \mathrm{MPa}$. Although accurate measurements are dependent on the observer, the direct observation of the phase equilibrium and the small amounts of sample required are clear advantages of this method. But even to confirm the accuracy some points were randomly repeated and the maximum deviation obtained was $0.2^{\circ} \mathrm{C}$.

\subsection{Solubility measurements}

The amount of carbon dioxide incorporated in the lipid matrices was measured by for three different temperatures each, in a pressure range from 10 to $20 \mathrm{MPa}$. The measurements were performed using the high-pressure apparatus shown in Fig. 2, using a similar method to the one described by Matias et al. [20]. A stainless steel cell, with sapphire windows and an internal volume of approximately $60 \mathrm{~cm}^{3}$, is loaded with about $10 \mathrm{~g}$ of the lipid carrier and placed in a thermostated air bath heated by means of a controller that maintained temperature within $\pm 0.1^{\circ} \mathrm{C}$. The system is then pressurized with fresh carbon dioxide until the desired pressure is brought into the cell, with an error of $\pm 0.007 \mathrm{MPa}$ and the mixture is magnetically stirred. At the fixed temperature, a typical equilibration time is $1 \mathrm{~h}$. After $30 \mathrm{~min}$ of rest for equilibration, samples from the liquid phase are withdrawn through a high-pressure valve system, which is locally heated to avoid solidification of the samples upon pressure drops. The liquid samples were collected by quick depressurization and expansion into a small glass trap and the gas in them contained is further expanded into a calibrated volume at sub-atmospheric pressure. The amount of $\mathrm{CO}_{2}$ in each sample is calculated from the increase of the resulting sub-atmospheric pressure at the working temperature: the number of $\mathrm{CO}_{2}$ moles was determined from the measured gas volume using the second virial coefficient EOS. The sampling valve system is later flushed with chloroform to ensure all the product is collected and the amount of product is obtained by weighing after solvent evaporation in a vacuum chamber. Each data point obtained is the result of at least three measurements, with a maximum absolute relative deviation, AARD of $9 \%$.

$\operatorname{AARD}(\%)=\frac{100}{n} \sum_{1}^{n} \frac{\left|S_{\text {calc }}-S_{\text {exp }}\right|}{S_{\text {calc }}}$

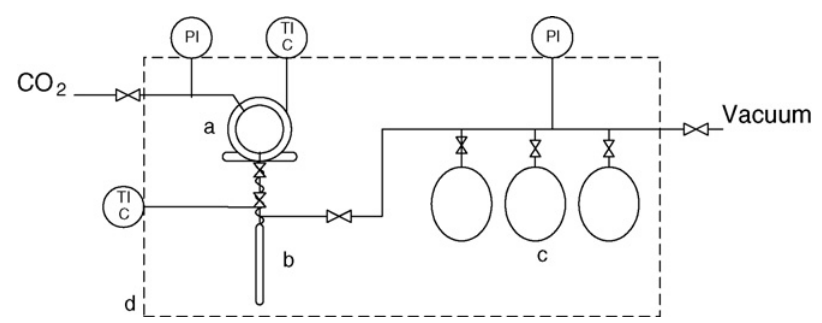

Fig. 2. High-pressure apparatus for solubility measurements: (a) sapphirewindowed visual cell; (b) sampling glass trap; (c) expansion volume; (d) air bath; (PI) pressure indicator; (TIC) temperature controller. 
where $S_{\exp }$ and $S_{\text {calc }}$ are the experimental solubilities and the calculated average for $n$ data points, respectively.

\subsection{Analytical determination of the mixtures' composition}

Lipid samples before and after melting were submitted to GC analysis to evaluate if the relative composition of the mixtures remained the same, or if fractionation occurred after melting and sampling. This method was standardized by the IUPAC and constitutes the basis of some European Regulations for determination of fatty acids. A separation capillary column Supelco SP-2380, $60 \mathrm{~m} \times 0.32 \mathrm{~mm}$ with a film thickness of $0.2 \mu \mathrm{m}$ and split injection was used. Hydrogen was used as the gas carrier with a column inlet pressure of $100 \mathrm{kPa}$ and a split of $120 \mathrm{~mL} / \mathrm{min}$. The samples were dissolved in heptane and $1 \mu \mathrm{L}$ was injected. The temperature program was $50{ }^{\circ} \mathrm{C}$ for $5 \mathrm{~min}$, then at $4{ }^{\circ} \mathrm{C} / \mathrm{min}$ to $250^{\circ} \mathrm{C}$ hold for $25 \mathrm{~min}$, with an initial temperature of the injector and the detector of $275^{\circ} \mathrm{C}$. The results were compared with a commercial standard solution Supelco FAME Mix $\mathrm{C}_{14}-\mathrm{C}_{22}$ in the same conditions.

\section{Results and discussion}

The experimental data for the variation of the melting points of Precirol ${ }^{\circledR}$ ATO5, Compritol ${ }^{\circledR} 888$ ATO and Gelucire ${ }^{\circledR} 43-01$ in the presence of carbon dioxide up to pressures of $30 \mathrm{MPa}$ are presented in Fig. 3 and Table 1. A maximum decrease of $13^{\circ} \mathrm{C}$ for Precirol ${ }^{\circledR}$ ATO5, $5^{\circ} \mathrm{C}$ for Compritol ${ }^{\circledR} 888$ ATO and of $12^{\circ} \mathrm{C}$ for Gelucire ${ }^{\circledR}$ 43-01, was observed when increasing carbon dioxide pressures up to approximately $10 \mathrm{MPa}$. For higher pressures a slight increase is observed, but the melting domain remains approximately constant.

This behaviour is explained by two competing phenomena: on one hand, the increase of the hydrostatic pressure increases the melting temperature of the compounds; on the other hand, if a gas is dissolved in a heavy substance the melting tempera-

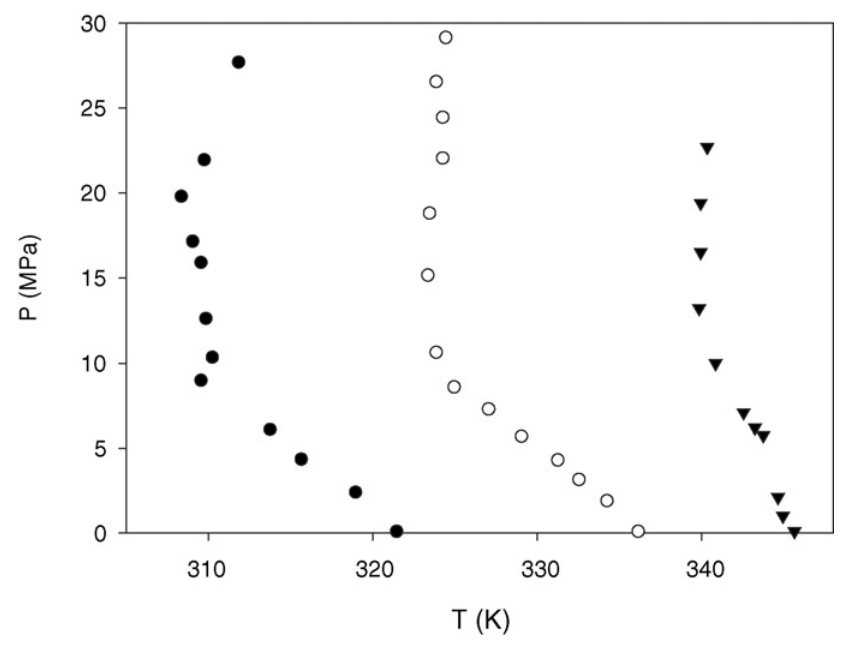

Fig. 3. Melting points of Precirol ${ }^{\circledR}$ ATO5 $(\bigcirc)$, Compritol $^{\circledR} 888$ ATO $(\boldsymbol{\Lambda})$ and Gelucire $^{\circledR}$ 43-01 (-) in the presence of carbon dioxide.

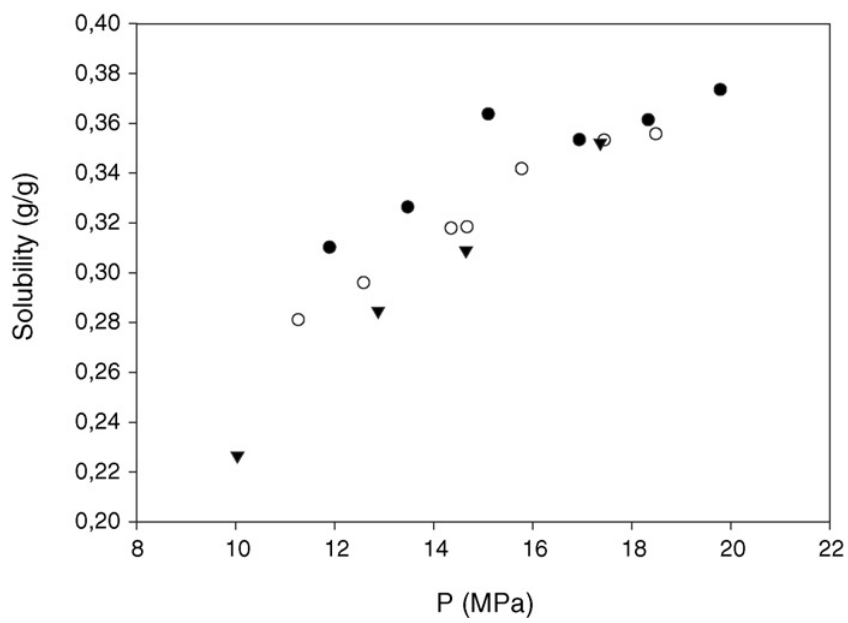

Fig. 4. Solubility of carbon dioxide in Precirol ${ }^{\circledR}$ ATO5 at $(\bigcirc) 328 \mathrm{~K},(\bullet) 323 \mathrm{~K}$ and (4) $333 \mathrm{~K}$.

Table 1

Melting points of Precirol ${ }^{\circledR}$ ATO5, Compritol ${ }^{\circledR} 888$ ATO and Gelucire ${ }^{\circledR} 43-01$ in the presence of carbon dioxide

\begin{tabular}{|c|c|c|c|c|c|}
\hline \multicolumn{2}{|l|}{ Gelucire $^{\circledR} 43-01$} & \multicolumn{2}{|l|}{ Precirol ${ }^{\circledR}$ ATO5 } & \multicolumn{2}{|c|}{ Compritol $^{\circledR} 888$ ATO } \\
\hline Temperature (K) & Pressure (MPa) & Temperature (K) & Pressure (MPa) & Temperature (K) & Pressure (MPa) \\
\hline 308.4 & 19.80 & 323.3 & 15.15 & 340.4 & 22.70 \\
\hline 309.0 & 17.15 & 323.5 & 18.80 & 340.0 & 19.40 \\
\hline 309.6 & 15.90 & 323.8 & 10.65 & 340.1 & 16.50 \\
\hline 309.6 & 9.00 & 323.9 & 26.55 & 339.9 & 13.20 \\
\hline 309.8 & 21.95 & 324.2 & 22.05 & 340.9 & 10.00 \\
\hline 309.9 & 12.60 & 324.3 & 24.45 & 342.6 & 7.10 \\
\hline 310.3 & 10.35 & 324.5 & 29.15 & 343.3 & 6.20 \\
\hline 311.9 & 27.70 & 325.0 & 8.60 & 343.8 & 5.75 \\
\hline 313.8 & 6.10 & 327.0 & 7.30 & 344.7 & 2.10 \\
\hline 315.7 & 4.35 & 329.1 & 5.70 & 345.0 & 1.00 \\
\hline 319.0 & 2.40 & 331.3 & 4.30 & 345.7 & 0.10 \\
\hline \multirow[t]{3}{*}{321.5} & 0.10 & 332.6 & 3.15 & & \\
\hline & & 334.3 & 1.90 & & \\
\hline & & 336.2 & 0.10 & & \\
\hline
\end{tabular}


Table 2

Solubilities of carbon dioxide in Precirol ${ }^{\circledR}$ ATO5

\begin{tabular}{|c|c|c|c|c|c|c|c|c|}
\hline \multicolumn{3}{|c|}{ Temperature $=323.0 \mathrm{~K}$} & \multicolumn{3}{|c|}{ Temperature $=328.0 \mathrm{~K}$} & \multicolumn{3}{|c|}{ Temperature $=333.0 \mathrm{~K}$} \\
\hline $\begin{array}{l}\text { Pressure } \\
(\mathrm{MPa})\end{array}$ & $\begin{array}{l}\text { Solubility } \\
{\text { ( } \mathrm{gO}_{2} / \mathrm{g} \mathrm{Precirol}^{\circledR}}^{\circledR} \\
\text { ATO5) }\end{array}$ & $\begin{array}{l}\text { Solubility } \\
\text { (mass fraction) }\end{array}$ & $\begin{array}{l}\text { Pressure } \\
(\mathrm{MPa})\end{array}$ & $\begin{array}{l}\text { Solubility } \\
{\text { ( } \mathrm{gCO}_{2} / \mathrm{g} \mathrm{Precirol}^{\circledR}}^{{ }^{\circledR}} \\
\text { ATO5) }\end{array}$ & $\begin{array}{l}\text { Solubility } \\
\text { (mass fraction) }\end{array}$ & $\begin{array}{l}\text { Pressure } \\
(\mathrm{MPa})\end{array}$ & $\begin{array}{l}\text { Solubility } \\
\text { ( COO }_{2} / \mathrm{g} \mathrm{Precirol}^{\circledR} \\
\text { ATO5) }\end{array}$ & $\begin{array}{l}\text { Solubility } \\
\text { (mass fraction) }\end{array}$ \\
\hline 11.90 & 0.31 & 0.24 & 11.27 & 0.28 & 0.23 & 10.04 & 0.23 & 0.18 \\
\hline 13.48 & 0.33 & 0.25 & 12.59 & 0.30 & 0.23 & 12.88 & 0.28 & 0.22 \\
\hline 15.10 & 0.36 & 0.27 & 14.35 & 0.32 & 0.23 & 14.65 & 0.31 & 0.23 \\
\hline 18.34 & 0.36 & 0.27 & 15.78 & 0.34 & 0.25 & & & \\
\hline \multirow[t]{2}{*}{19.79} & 0.37 & 0.27 & 17.45 & 0.35 & 0.26 & & & \\
\hline & & & 18.49 & 0.36 & 0.26 & & & \\
\hline
\end{tabular}

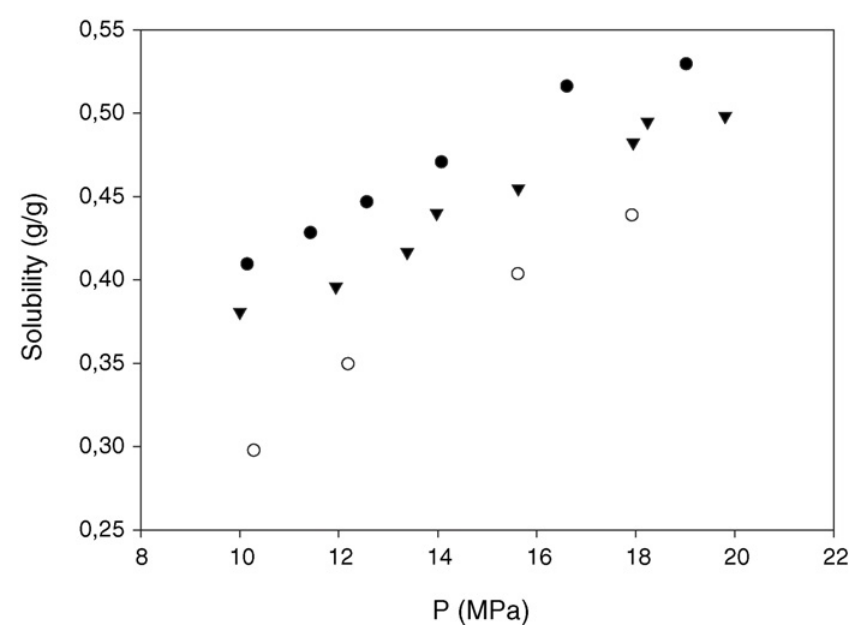

Fig. 5. Solubility of carbon dioxide in Gelucire ${ }^{\circledR} 43-01$ at $(\bigcirc) 326 \mathrm{~K}$, and (ム) $318 \mathrm{~K}$.

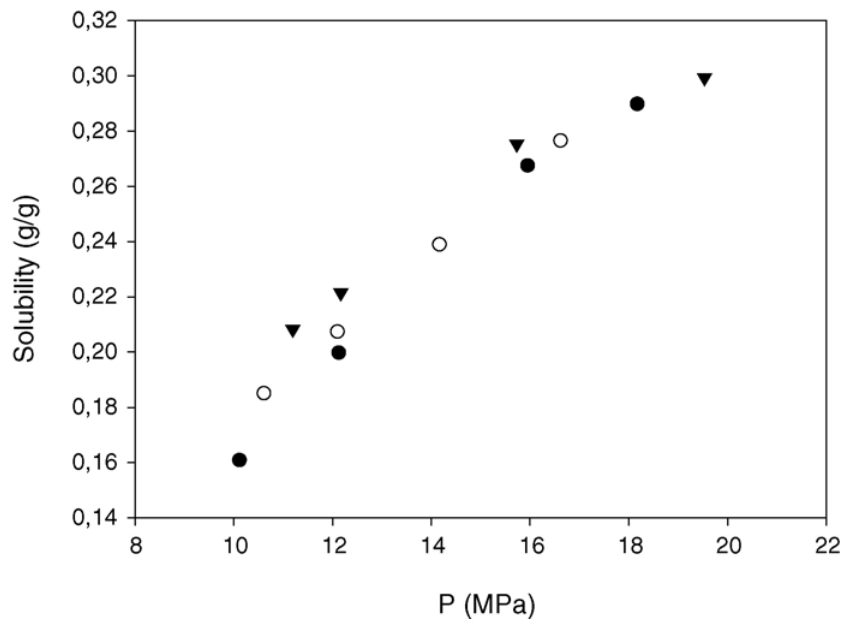

Fig. 6. Solubility of carbon dioxide in $\mathrm{Compritol}^{\circledR} 888$ ATO at (○) $344 \mathrm{~K}$, $340 \mathrm{~K}$ and $(\mathbf{\Delta}) 348 \mathrm{~K}$.

Table 3

Solubilities of carbon dioxide in Gelucire ${ }^{\circledR}$ 43-01

\begin{tabular}{|c|c|c|c|c|c|c|c|c|}
\hline \multicolumn{3}{|c|}{ Temperature $=326.0 \mathrm{~K}$} & \multicolumn{3}{|c|}{ Temperature $=310.0 \mathrm{~K}$} & \multicolumn{3}{|c|}{ Temperature $=318.0 \mathrm{~K}$} \\
\hline $\begin{array}{l}\text { Pressure } \\
(\mathrm{MPa})\end{array}$ & $\begin{array}{l}\text { Solubility } \\
\left(\mathrm{g} \mathrm{CO}_{2} / \mathrm{g} \mathrm{Gelucire}^{\circledR}\right. \\
43-01)\end{array}$ & $\begin{array}{l}\text { Solubility } \\
\text { (mass fraction) }\end{array}$ & $\begin{array}{l}\text { Pressure } \\
(\mathrm{MPa})\end{array}$ & $\begin{array}{l}\text { Solubility } \\
\left(\mathrm{g} \mathrm{CO}_{2} / \mathrm{g} \text { Gelucire }\right. \\
43-01)\end{array}$ & $\begin{array}{l}\text { Solubility } \\
\text { (mass fraction) }\end{array}$ & $\begin{array}{l}\text { Pressure } \\
(\mathrm{MPa})\end{array}$ & $\begin{array}{l}\text { Solubility } \\
\left(\mathrm{g} \mathrm{CO}_{2} / \mathrm{g} \text { Gelucire }\right. \\
43-01)\end{array}$ & $\begin{array}{l}\text { Solubility } \\
\text { (mass fraction) }\end{array}$ \\
\hline 10.15 & 0.41 & 0.29 & 10.28 & 0.30 & 0.23 & 10.00 & 0.38 & 0.28 \\
\hline 11.43 & 0.43 & 0.30 & 12.19 & 0.35 & 0.26 & 11.94 & 0.40 & 0.28 \\
\hline 12.57 & 0.45 & 0.31 & 15.62 & 0.40 & 0.29 & 13.38 & 0.42 & 0.29 \\
\hline 14.08 & 0.47 & 0.32 & 17.92 & 0.44 & 0.31 & 13.98 & 0.44 & 0.31 \\
\hline 16.61 & 0.52 & 0.34 & & & & 15.63 & 0.45 & 0.31 \\
\hline \multirow[t]{3}{*}{19.02} & 0.53 & 0.35 & & & & 17.95 & 0.48 & 0.33 \\
\hline & & & & & & 18.24 & 0.49 & 0.33 \\
\hline & & & & & & 19.81 & 0.50 & 0.33 \\
\hline
\end{tabular}

Table 4

Solubilities of carbon dioxide in Compritol $^{\circledR} 888$ ATO

\begin{tabular}{|c|c|c|c|c|c|c|c|c|}
\hline \multicolumn{3}{|c|}{ Temperature $=340.0 \mathrm{~K}$} & \multicolumn{3}{|c|}{ Temperature $=344.0 \mathrm{~K}$} & \multicolumn{3}{|c|}{ Temperature $=348.0 \mathrm{~K}$} \\
\hline $\begin{array}{l}\text { Pressure } \\
(\mathrm{MPa})\end{array}$ & 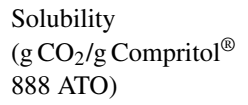 & $\begin{array}{l}\text { Solubility } \\
\text { (mass fraction) }\end{array}$ & $\begin{array}{l}\text { Pressure } \\
(\mathrm{MPa})\end{array}$ & 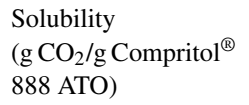 & $\begin{array}{l}\text { Solubility } \\
\text { (mass fraction) }\end{array}$ & $\begin{array}{l}\text { Pressure } \\
(\mathrm{MPa})\end{array}$ & 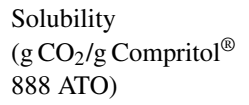 & $\begin{array}{l}\text { Solubility } \\
\text { (mass fraction) }\end{array}$ \\
\hline 10.11 & 0.16 & 0.17 & 10.61 & 0.18 & 0.16 & 11.20 & 0.21 & 0.14 \\
\hline 12.13 & 0.20 & 0.18 & 12.10 & 0.21 & 0.17 & 12.17 & 0.22 & 0.17 \\
\hline 15.95 & 0.27 & 0.22 & 14.16 & 0.24 & 0.19 & 15.73 & 0.27 & 0.21 \\
\hline
\end{tabular}


ture decreases, this prevails on the first part of the curve. This behaviour is a common one for fats and the melting point depression seems to be in the same order of magnitude from one fat to another. As an example, Elvassore et al. [21] measured the melting point of tristearin and the results are similar to ours. The rather scattered data obtained for the upper part of the melting curves, could be explained due to the fact that a visual method was employed, but most certainly the main reason is the polymorphic forms these compounds can assume, meaning that in

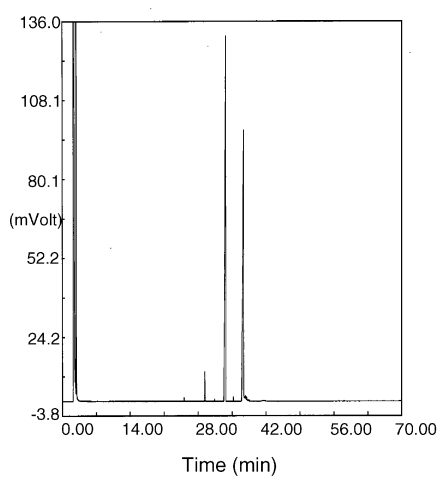

Precirol® ATO5 after solubility measurements

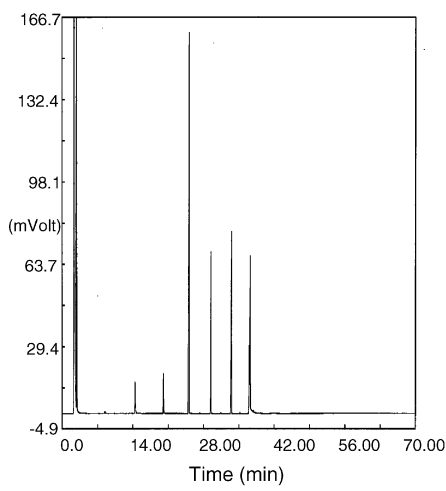

Gelucire $\circledR^{8} 43-01$ before solubility measurements

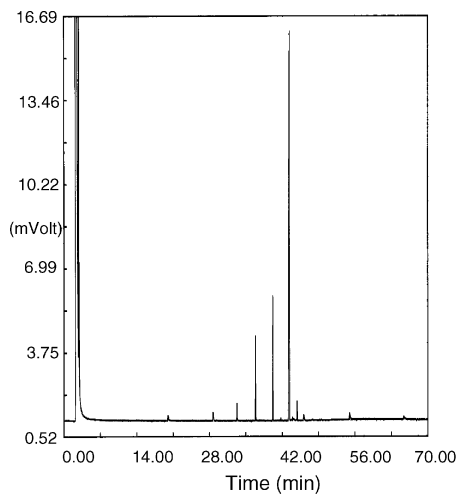

Compritol 8888 ATO before solubility measurements some cases probably the predominant solid phase present was not the same.

The solubility of carbon dioxide in Precirol ${ }^{\circledR}$ ATO5 $\left(\mathrm{C}_{16}\right.$ and $\mathrm{C}_{18}$ ) was measured in a pressure range from 10 to $20 \mathrm{MPa}$, at 323,328 and $333 \mathrm{~K}$. For Compritol ${ }^{\circledR} 888$ ATO $\left(\mathrm{C}_{22}\right)$ and for Gelucire ${ }^{\circledR} 43-01\left(\mathrm{C}_{12}-\mathrm{C}_{18}\right)$ the measurements were performed in the same pressure range but at 340,344 and $348 \mathrm{~K}$ for the first and at 310,318 and $326 \mathrm{~K}$ for the latter. These data are presented in Figs. 4-6 and in Tables 2-4. The composition of

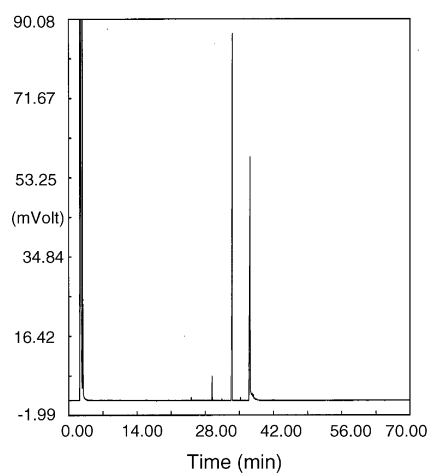

Precirol® ATO5 after solubility measurements

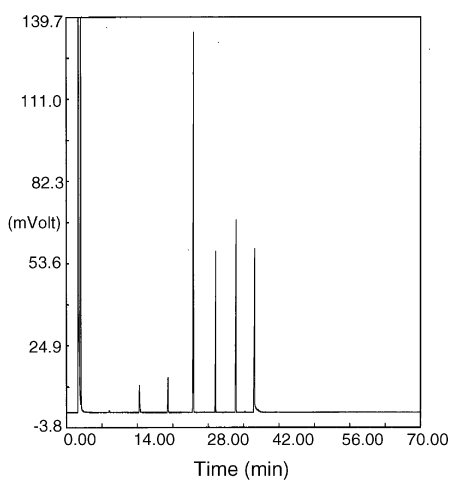

Gelucire $® 43-01$ after

solubility measurements

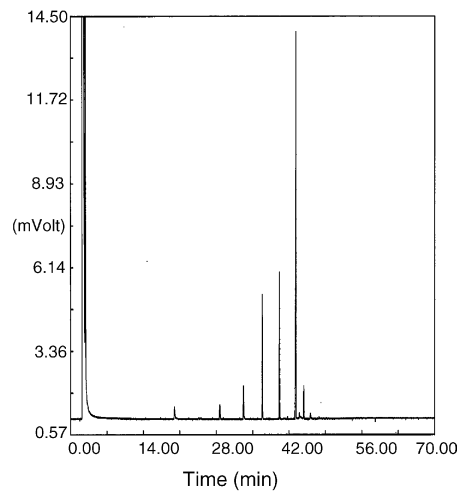

Compritol@ 888 ATO after solubility measurements

Fig. 7. Chromatograms of Precirol ${ }^{\circledR}$ ATO5, Compritol ${ }^{\circledR} 888$ ATO and Gelucire ${ }^{\circledR} 43-01$ before and after solubility measurements. 
carbon dioxide in the heavy phase increases with pressure up to a maximum, and decreases with increasing temperature. This occurs because the density of the fluid decreases, and its vapour pressure increases with increasing temperature, thus making it less soluble in the molten mixture.

Comparing the data obtained with the structure of the different compounds, the shorter the carbon chains, the greater amount of carbon dioxide is incorporated. The fact that Precirol ${ }^{\circledR}$ ATO5 and Gelucire ${ }^{\circledR}$ 43-01 have some common composition also explains the similar variation $\left(13\right.$ and $12{ }^{\circ} \mathrm{C}$, respectively) in the melting in the presence of carbon dioxide.

The GC analysis showed no significant change in the relative compositions of the lipid mixtures (Fig. 7). This is important because even if there is some solubility of the mixture components in the vapour phase, which probably will happen since the solubility in carbon dioxide of some of the pure components of the mixtures used in this study has already been reported [22], there is no fractionation and the overall composition remains the same, meaning the properties of Precirol ${ }^{\circledR}$ ATO5, Compritol ${ }^{\circledR}$ 888 ATO and Gelucire ${ }^{\circledR} 43-01$ as biocarriers for active ingredients also remain the same.

\section{Conclusions}

In this work the incorporation of carbon dioxide in two lipid matrices was studied using two different methods. The measurement of the melting point variation of the compounds in the presence of carbon dioxide, for pressures up to $30 \mathrm{MPa}$, gave a qualitative idea of the amount incorporated; this amount was later quantified by results of the solubility experiments, carried out in pressures from 10 to $20 \mathrm{MPa}$, and for three different temperatures for each compound with a maximum relative deviation, AARD, of $9 \%$.

For Precirol ${ }^{\circledR}$ ATO5 it was found that the melting point could decrease up to $13{ }^{\circ} \mathrm{C}$ in the presence of carbon dioxide, and its solubility increases at constant temperature up to a maximum of approximately $0.4 \mathrm{~g} / \mathrm{g}$ of Precirol ${ }^{\circledR}$ ATO5. The melting point of Compritol ${ }^{\circledR} 888$ ATO decreases only $5{ }^{\circ} \mathrm{C}$ and it can incorporate carbon dioxide up to a maximum of $0.3 \mathrm{~g} / \mathrm{g}$ of Compritol ${ }^{\circledR}$ 888 ATO. Finally for Gelucire ${ }^{\circledR} 43-01$ the melting point depression obtained is $12{ }^{\circ} \mathrm{C}$ lower than at atmospheric pressure, and the solubility of carbon dioxide also increases with pressure up to approximately $0.5 \mathrm{~g} / \mathrm{g}$ of Gelucire ${ }^{\circledR} 43-01$. The temperature effect is the opposite, for the same pressure, solubility decreases with increasing temperature.

This is the main reason why it is so important to know the high-pressure equilibrium behaviour. If we can operate at lower temperatures and still have maximum incorporation of carbon dioxide in the lipid matrices, the supercritical particle formation process can later be designed more effectively in terms of yield and energy.

\section{Acknowledgements}

A.R. Sampaio de Sousa is grateful for the SFRH/BD/14403/2003 grant from Fundação para a Ciência e Tecnologia, Portugal. The authors would also like to thank the financial support from FCT (Portugal) through POCI/CTM/61770/2004 as well as Interreg Program (through Supermat Network).

\section{References}

[1] R.H. Müller, C. Keck, Challenges and solutions for the delivery of biotech drugs - a review of drug nanocrystal technology and lipid nanoparticles, J. Biotechnol. 113 (2004) 151.

[2] S.A. Wissing, O. Kayser, R.H. Müller, Solid lipid nanoparticles for parenteral drug delivery, Adv. Drug Delivery Rev. 56-9 (2004) 1257.

[3] J. Hamdani, A.J. Moës, K. Amighi, Physical and thermal characterisation of Precirol ${ }^{\circledR}$ and Compritol ${ }^{\circledR}$ as lipophilic glycerides used for the preparation of controlled-release matrix pellets, Int. J. Pharm. 26 (2003) 47.

[4] Gattefossé, Product Information Brochure.

[5] A. del Pozo, M.A. Solinis, A.R. Gascon, A.M. Carcaboso, A. Esquisabel, J.L. Pedraz, Elaboration and characterization of SLN as a DNA delivery system, in: Proceedings of the XII International Workshop on Bioencapsulation, Vitoria, Spain, 24-26 September, 2004, p. 198.

[6] P. Caybasi, Y. Özsoy, T. Tunçel, Investigations on the lipophilic matrix tablets prepared with Precirol ATO 5 of verapamil hydrochloride, Eur. J. Pharm. Sci. 6-1 (1998) S63.

[7] J. Liu, F. Zhang, J.W. Mc Ginity, Properties of lipophilic matrix tablets containing phenylpropanolamine hydrochloride prepared by hot-melt extrusion, Eur. J. Pharm. Biopharm. 52-2 (2001) 181.

[8] J. Hamdani, A.J. Moës, K. Amighi, Development and evaluation of prolonged release pellets obtained by the melt pelletization process, Int. J. Pharm. 245 (2002) 167.

[9] G. Dupont, M.P. Flament, P. Leterme, N. Farah, A. Gayot, Developing a study method for producing $400 \mu \mathrm{m}$ spheroids, Int. J. Pharm. 247 (1-2) (2002) 159.

[10] B. Albertini, N. Nadia Passerini, M.L. González-Rodríguez, B. Perissutti, L. Rodriguez, Effect of Aerosil ${ }^{\circledR}$ on the properties of lipid controlled release microparticles, J. Controlled Release 100 (2) (2004) 233.

[11] T.-J. Wang, A. Tsutsumi, H. Hasegawa, T. Mineo, Mechanism of particle coating granulation with RESS process in a fluidized bed, Powder Technol. 118 (2001) 229.

[12] M. Charoenchaitrakool, F. Dehghani, N.R. Foster, Micronization by rapid expansion of supercritical solutions to enhance the dissolution rates of poorly water-soluble pharmaceuticals, Ind. Eng. Chem. Res. 39 (2000) 4794.

[13] E. Reverchon, Supercritical antisolvent precipitation of micro- and nanoparticles, J. Supercrit. Fluids 15 (1999) 1.

[14] J. Kerc, S. Srcic, Z. Knez, P. Sencar-Bozi, Micronization of drugs using supercritical carbon dioxide, Int. J. Pharm. 182 (1999) 33.

[15] P. Alessi, A. Cortesi, I. Kikic, N.R. Foster, S.J. Macnaughton, I. Colombo, Particle production of steroid drugs using supercritical fluid processing, Ind. Eng. Chem. Res. 35 (1996) 4718.

[16] E. Weidner, Z. Knez, Z. Novak, Process for the production of particles or powders, US Patent 6,056,791 (2000).

[17] A. Bertucco, M.J. Cocero, T. Gamse, P. Hamley, I. Kikic, T. de Loos, L. Kleintjens, Z. Knez, E. Lack, G. Luft, F. Recasens, C. Schaschke, B. Simandi, D. skala, H. Sovova, E. Velo, Socrates Intensive Program on High Pressure Chemical Engineering Processes, Barcelona, 2004.

[18] J. Jung, M. Perrut, Particle design using supercritical fluids: literature and patent survey, J. Supercrit. Fluids 20 (2001) 179

[19] K. Fukné-Kokot, A. König, Z. Knez, M. Skerget, Comparison of different methods for determination of S-L-G equilibrium curve of a solid component in the presence of a compressed gas, Fluid Phase Equilib. 173 (2000) 297. 
[20] A.A. Matias, A.V.M. Nunes, T. Casimiro, C.M.M. Duarte, Solubility of coenzyme Q10 in supercritical carbon dioxide, J. Supercrit. Fluids 28 (2004) 201.

[21] N. Elvassore, M. Flaibani, A. Bertucco, P. Caliceti, Thermodynamic analysis of micronization processes from gas-saturated solution, Ind. Eng. Chem. Res. 42 (2003) 5924.
[22] T. Bamberger, J.C. Erickson, C.L. Cooney, S.K. Kumar, Measurement and model prediction of solubilities of pure fatty acids, pure triglycerides, and mixtures of triglycerides in supercritical carbon dioxide, J. Chem. Eng. Data 33 (1988) 327. 